\title{
Tugas Dan Peran Guru Menurut Perspektif Pendidikan Islam
}

\author{
Yazidul Busthomi \\ Institut Agama Islam Al-Qolam Gondanglegi Malang, Indonesia \\ Email: busthomi@alqolam.ac.id \\ Syamsul A'dlom \\ Institut Agama Islam Al-Qolam Gondanglegi Malang, Indonesia \\ Email: syadlom@alqolam.ac.id
}

\begin{abstract}
Being a teacher is a really noble job. He is responsible not only to make human children smart in the field of science, but also to have good morals in this life. A human child who at first does not understand anything, in front of a teacher is educated to understand life better and know the world. On his shoulders are the duties and responsibilities for the future sustainability of a generation that is smarter and more civilized. So noble is the job of a teacher as well as how heavy the task and responsibility of being a teacher is. This is why not everyone can be a successful teacher. Only certain people who have a love for children or students and are highly dedicated to the world of education are able to become teachers. This is the personality of a teacher who successfully teaches and educates in front of his students, the figure of a favorite teacher who is loved by his students. According to the perspective of Islamic education, in addition to serving as coaches and educators of students, teachers also have duties and roles as follows: 1.Corrector, 2.Inspirator, 3.Informer, 4.Organisator, 5.Motivator, 6.Initiator, 7. Facilitator, 8.Supervisor, 9.Demonstrator, 10.Class Manager, 11. Mediator, 12.Supervisor, 13.Evalator.
\end{abstract}

Keywords: Task, Role, Teacher

\section{Pendahuluan}

Pendidikan adalah suatu aktivitas untuk mengembangkan seluruh aspek kepribadian manusia yang berjalan seumur hidup (Zuhairini, 2005, p.149). Pendidikan pada hakikatnya adalah pengembangan potensi atau kemampuan manusia secara menyeluruh yang pelaksanaannya dilakukan dengan cara mengajarkan pelbagai pengetahuan dan kecakapan yang dibutuhkan oleh manusia itu sendiri. Pendidikan adalah tahapan pengubahan sikap dan tingkah laku manusia baik sebagai individu maupun sebagai kelompok melalui ikhtiar pengajaran dan pelatihan. Dalam perspektif psikologi, pelatihan sebenarnya masih berada dalam ruang lingkup pengajaran. Artinya, pelatihan adalah salah satu unsur pelaksanaan proses pengajaran terutama dalam pengajaran keterampilan rana karsa (Muhibbin Syah, 2008, p.35).

Apabila pendidikan dianggap jauh berbeda dengan pengajaran adalah persepsi yang salah. Pengajaran boleh jadi tidak sama persis dengan pendidikan, tetapi tidak berarti di antara keduanya terdapat jurang pemisah yang mengakibatkan timbulnya perbedaan 
yang mencolok. Pendidikan boleh juga dipandang lebih utama dari pada pengajaran. Namun, sulit dipercaya apabila ada seuah sistem pendidikan dapat berjalan tanpa pengajaran. Oleh karena itu, pengajaran dengan segala bentuk perwunjudannya sepantasnya dipandang sebagai konsep operasional yang berposisi kurang lebih setara dengan pendidikan sebagai konsep ideal (Muhibbin Syah, 2008, p.36).

Pendidikan adalah bimbingan atau pimpinan secara sadar oleh pendidik terhadap perkembangan jasmani dan rohani anak didik menuju terbentuknya kepribadian yang utama (Ahmad Tafsir, 2014, p.24). Sekolah merupakan lembaga pendidikan formal yang mana sistem pendidikannya sudah terstruktur dengan baik. Lembaga pendidikan formal memiliki beberapa ciri-ciri yaitu: pembelajaran dilakukan di dalam ruang kelas, baik kelas yang sebenarnya maupun kelas online, dalam pendidikan formal ada batasan usia adanya batasan usia sesuai dengan jenjang pendidikan misalnya jenjang MI Mts, dan MA, memiliki administrasi pendidikan dan manajemen kurikulum yang jelas. Adapun jenjang lembaga pendidikan formal yaitu TK/RA, SD/MI, SMP/MTS, SMK/MA, dan universitas, institut, atau sekolah tinggi.

Lembaga pendidikan non formal seperti taman pendidikan Al-Qur'an (TPQ) dan pondok pesantren, taman pendidikan Al-Qur'an (TPQ) merupakan tempat atau lembaga yang memberikan pengajaran membaca Al-Qur'an pada anak, yang mana kurikulumnya menekankan pada dasar-dasar membaca Al-Qur'an, pada zaman dahulu kitab yang digunakan Iqra' untuk anak yang baru memulai belajar membaca, dengan seiring berkembangnya zaman banyak sekali metode yang digunakan dalam mempelajari dasardasar membaca Al-Qur'an, misalnya metode уапьииa, at-tartil, Qiraati, dan lain-lain.

Sedangkan pendidikan pesantren adalah sebuah asrama pendidikan Islam tradisional yang para santrinya tinggal bersama dan belajar di bawah bimbingan guru yang lebih dikenal dengan sebutan kiai dan dimana sang kiai juga bertempat tinggal di situ dengan fasilitas utama berupa musholla/langgar/masjid sebagai tempat ibadah, ruang belajar, dan pusat kegiatan keagamaan lainnya. Kompleks ini pada umumnya di kelilingi pagar atau dinding tembok yang berguna untuk mengontrol keluar-masuknya santri menurut peraturan yang berlaku di suatu pesantren, misalnya pondok pesantren Raudlatul Ulum 1 Ganjaran Gondanglegi Malang. Pendidikan pesantren memiliki tujuan pendidikan yang khas untuk membentuk seorang mukmin yang senantiasa taat kepada perintah agama serta menguasai bagaimana tata cara melaksakana perintah agama (Fatih syuhud, 2008, p.7). 
Selain itu tujuan dari pendidikan pesantren itu untuk mencetak peserta didiknya menjadi manusia yang lebih baik serta bermanfaat bagi masrakat sekitarnya dimanapun mereka berada. Pendidikan formal dan non formal mempunyai hubungan yang sangat penting karena keduanya bisa saling melengkapi satu sama lain. Jika tidak dapat memperoleh pengetahuan dalam pendidikan formal maka akan diperoleh dari pendidikan non formal. Kedua pendidikan ini sangat penting dan saling berhubungan bukan hanya mengandalkan pendidikan formal saja melainkan pendidikan non formal, maka dari itu hendaknya menyeimbangkan antara pendidikan formal dan informal.

Tugas dan tanggungjawab seorang guru di sekolah/madrasah semakin berat karena tidak sedikit dari orangtua yang seakan mempercayakan sepenuhnya pendidikan anak-anaknya di sekolah. Mereka beranggapan bahwa tugas dan tanggung jawab orangtua adalah bekerja dan bekerja sehingga mempunyai uang yang banyak untuk memenuhi kebutuhan anak-anaknya, termasuk biaya sekolah. Bahkan, tidak sedikit orangtua yang berusaha dengan sekuat tenaga agar anak-anaknya dapat sekolah di tempat yang favorit meskipun biayanya mahal. Orangtua yang demikian biasanya telah merasa bahwa tugas dan tanggung jawabnya di bidang pendidikan anak-anaknya telah selesai. Mereka percaya sepenuhnya bahwa pihak sekolah telah mendidiknya dengan baik sehingga merasa tidak perlu lagi mengontrol pendidikan anaknya ketika di rumah. Sungguh, anggapan yang seperti itu tidaklah benar. Orangtua tetap bertanggung jawab terhadap pendidikan anakanaknya secara keseluruhan. Sedangkan, guru bertanggung jawab karena mendapatkan amanat dari orangtua untuk mendidik anak-anak mereka, di samping merupakan tanggung jawab kemanusiaan (Akhmad Muhaimin Azzet, 2011, p.18).

Disinilah sesungguhnya tugas dan tanggung jawab guru menjadi tidak mainmain. Amanat dari orang tua untuk mendidik anak-anaknya mesti ditunaikan dengan sangat baik. Guru tidak sekedar mengajar, tetapi juga mendidik anak didiknya. Dengan demikian, seorang guru bisa dikatakan sebagai orang tua kedua bagi anak didiknya. Sebagai orangtua kedua, sudah tentu dibutuhkan kedekatan dengan anak didiknya agar berhasil dalam menjalankan tugas penting dan mulia ini.

Kedekatan dengan anak didik adalah kunci penting bagi seorang guru bila ingin sukses dalam menjalankan tugas dan tanggung jawabnya. Tanpa kedekatan, tugas dan tanggung jawab itu akan sulit dapat terlaksana dengan baik karena anak didik bukanlah robot yang siap menerima program apa pun dari orang yang membuat atau mengoperasikannya. Anak didik adalah pribadi yang mempunyai jiwa. Sudah tentu, 
menghadapi pribadi yang mempunyai jiwa dibutuhkan kedekatan di antara dua jiwa agar komunikasi dalam proses pembelajaran dapat berjalan dengan baik.

Menjadi guru adalah pekerjaan yang sungguh mulia. Ia bertanggung jawab tidak hanya menjadikan para anak manusia pandai di bidang ilmu pengetahuan, tetapi juga bermoral baik dalam kehidupan ini. Seorang anak manusia yang pada mulanya tidak mengerti apa-apa, di hadapan seorang guru dididik untuk memahami kehidupan secara lebih baik dan mengenal dunia. Di pundaknyalah ada tugas dan tanggung jawab keberlangsungan masa depan generasi yang lebih cerdas dan berperadapan (Akhmad Muhaimin Azzet, 2011, p.13).

Begitu mulia pekerjaan seorang guru sekaligus betapa berat tugas dan tanggung jawab menjadi seorang guru. Inilah mengapa tidak semua orang bisa menjadi seorang guru yang berhasil. Hanya orang-orang tertentu yang mempunyai rasa cinta terhadap anak-anak atau peserta didik dan berdedikasi tinggi terhadap dunia pendidikan saja yang mampu menjadi seorang guru. Inilah pribadi seorang guru yang berhasil mengajar sekaligus mendidik di hadapan murid-muridnya, sosok seorang guru favorit yang dicintai oleh anak didiknya.

Motivasi dan kecintaan seseorang untuk menjadi guru adalah dasar bagi seorang guru akan sukses dan dicintai oleh murid-muridnya atau tidak. Motivasi dan kecintaan ini harus terpancang sejak awal seseorang menekuni profesi sebagai guru atau bisa pula baru terbangunkan setelah seseorang menjalani profesi ini sekian waktu. Motivasi dan kecintaan ini harus senantiasa dijaga agar seorang tetap bersemangat menghadapi anak didiknya dalam proses pembelajaran. Jadi, motivasi dan kecintaan ini semacam ruh bagi seorang guru agar selalu dekat dengan anak didiknya sehingga apa yang disampaikan dalam pembelajaran mudah diterima. Inilah kunci penting bagi keberhasilan seorang guru dalam menjalankan tugas dan tanggung jawabnya. Seorang guru yang tidak hanya mencintai profesinya, tetapi juga dicintai oleh anak didiknya.

Menjadi guru yang mencintai profesi dan dicintai oleh anak didik betapa membahagiakan hati. Sebaliknya, menjadi guru yang sekadar sebagai profesi, biasanya juga akan sekadar dikenal saja oleh anak didiknya secara pribadi. Dalam hubungan yang semacam ini, terasa sekali tiada kedekatan antar-pribadi. Bila hal ini yang terjadi, proses pembelajaran akan berjalan datar-datar saja, serasa hambar, bahkan tidak jarang menjemukan (Yazidul Busthomi, 2018, p.94). 
Keberhasilan pendidikan di sekolah sangat ditentukan oleh Kepala Madrasah dalam mengelola tenaga kependidikan yang tersedia di sekolah. Dalam hal ini, peningkatan produktifitas dan prestasi kerja dapat dilakukan dengan meningkatkan perilaku tenaga kependidikan di sekolah melalui aplikasi berbagai konsep dan teknik management personalia moderen.

Management tenaga kependidikan di sekolah bertujuan untuk mendayagunakan tenaga kependidikan secara efektif dan efisien. Untuk mencapai hasil yang optimal namun tetap dalam kondisi yang menyenangkan. Sehubungan dengan itu fungsi management tenaga kependidikan yang ada di sekolah yang harus dilaksanakan Kepala Madrasah adalah menarik, mengembangkan, menggaji, memotivasi tenaga kependidikan guna mencapai tujuan pendidikan secara optimal, membantu tenaga kependidikan mencapai posisi dan standar perilaku, memaksimalkan perkembangan karir, serta menyelaraskan tujuan individu dan organisasi (Enco Mulyasa, 2011, p.151).

Kepala madrasah memiliki tanggung jawab yang besar di dalam merencanakan, mengorganisir, membina, melaksanakan serta mengendalikan madrasah dan sumber daya manusia yang ada di dalamnya. Guru merupakan unsur utama dalam pelaksanaan secara keseluruhan proses pendidikan Tanpa peran dan jasa guru, pendidikan hanya menjadi slogan karena segala bentuk kebijakan dan program pada akhirnya akan kembali ditentukan oleh kinerja guru.

Sebagai sebuah profesi, posisi guru tidak bisa didapatkan begitu saja. Para guru harus memiliki beberapa persyaratan seperti kualifikasi, kompetensi dan sertifikasi sebagai sebuah syarat profesional. Guru juga harus siap menyesuaikan diri dengan kurikulum yang sering berubah-ubah. Tidak hanya itu, guru dituntut memiliki kepribadian yang matang dan pastas ditiru oleh peserta didiknya, karena ia dapat mempengaruhi peserta didiknya. Pendidikan tidak hanya membuat peserta didik memiliki intelektual yang tinggi tetapi juga harus memiliki kepribadian yang baik. Karena setiap tingkah laku guru menjadi panutan bagi peserta didik.

Untuk itu peran guru di samping melaksanakan tugas pengajaran, ia juga harus melaksanakan tugas pendidikan dan pembinaan bagi anak didik, guru membantu pembentukan kepribadian akhlak serta menumbuhkan dan mengembangkan keimanan dan ketakwaan para peserta didik, maka untuk melaksanakan itu semua, guru dituntut untuk memiliki profesionalisme yang tinggi dan baik. Masalah yang berkaitan dengan guru dan keguruan biasanya berkisar pada permasalahan kurang memadainya kualifikasi dan 
kompetensi guru, dan kurangnya penghargaan terhadap profesi guru.

\section{Syarat-syarat Guru dalam Pandangan Islam}

Soejono menyatakan bahwa syarat-syarat guru adalah sebagai berikut:

1. Tentang umur, harus sudah dewasa

Tugas mendidik adalah tugas yang amat penting karena menyangkut perkembangan seseorang, jadi menyangkut nasib seseorang. Oleh karena itu, tugas itu harus dilakukan secara bertanggung jawab. Itu hanya dapat dilakukan oleh orang yang telah dewasa, anak-anak tidak dapat dimintai pertanggung jawaban.

2. Tentang kesehatan harus sehat jasmani dan rohani

Jasmani yang tidak sehat akan menghambat pelaksana pendidikan, bahkan dapat membahayakan anak didik bila mempunyai penyakit menular. Dari segi rohani, orang gila berbahaya juga bila ia mendidik. Orang idiot tidak mungkin mendidik karena ia tidak akan mampu bertanggung jawab.

3. Tentang kemampuan mengajar ia harus ahli

Ini penting sekali bagi pendidik, termasuk guru. Orang tua di rumah sebenarnya perlu sekali mempelajari teori-teori ilmu pendidikan. Dengan pengetahuan itu diharapkan ia akan lebih berkemampuan menyelenggarakan pendidikan bagi anakanaknya di rumah. Sering kali terjadi kelainan pada anak didik disebabkan oleh kesalahan pendidikan di dalam rumah tangga.

4. Harus berkesusilaan dan berdedikasi tinggi

Syarat ini penting dimiliki untuk melaksanakan tugas-tugas mendidik selain mengajar. Bagaimana guru akan memberikan contoh-contoh kebaikan bila ia sendiri tidak baik perangainya? Dedikasi tinggi tidak hanya diperlukan dalam mendidik selain mengajar, dedikasi tinggi diperlukan juga dalam meningkatkan mutu mengajar (Ahmad Tafsir, 2014, p.81).

Syarat-syarat menjadi guru yang baik adalah sebagai berikut:

1. Berijazah,

2. Sehat jasmani dan rohani,

3. Takwa kepada Tuhan dan berkelakuan baik,

4. Bertanggung jawab,

5. Berjiwa nasional (Yazidul Busthomi, 2021, p.275).

\section{Sifat-sifat Guru dalam Pandangan Islam}

Sifat-sifat guru dalam pandangan Islam sebagai berikut: 
1. Kasih sayang pada murid,

2. Senang memberi nasihat,

3. Senang memberi peringatan,

4. Senang melarang murid melakukan hal yang tidak baik,

5. Bijak dalam memilih bahan pelajaran yang sesuai dengan lingkungan murid,

6. Hormat pada pelajaran lain yang bukan pegangannya,

7. Bijak dalam memilih bahan pelajaran yang sesuai dengan lingkungan murid,

8. Mementingkan berfikir dan berijtihad,

9. Jujur dalam keilmuan,

10. Adil (Ahmad Tafsir, 2014, p.84).

Menurut al-Ghazali, terdapat beberpa sifat penting yang harus dimiliki oleh guru sebagai orang yang diteladani yaitu:

a. Amanah dan tekun bekerja,

b. Bersifat lemah lembut dan kasih sayang terhadap murid,

c. Dapat memahami dan berlapang dada dalam ilmu serta orang-orang yang mengajarkannya,

d. Tidak rakus pada materi,

e. Berpengetahuan luas,

f. Istiqamah dan memegang teguh prinsip (Yazidul Busthomi, 2021, p.276).

\section{Kode Etik Seorang Guru}

Kode etik merupakan sesuatu yang sangat penting. Sebab, kode etik adalah aturan-aturan untuk bertingkah laku sehingga pada profesi apapun tentu memiliki kode etiknya masing-masing. Apalagi kode etik merupakan salah satu syarat untuk sesuatu pekerjaan dapat dikatakan sebagai profesi. Ada beberapa kriteria yang menjadi standar yang harus dipenuhi sehingga suatu pekerjaan dapat dikatakan sebagai profesi di antara lain:

1. Harus mendapat pengakuan dari pemerintah dan masyarakat

2. Adanya kode etik

3. Mempunyai organisasi profesi yang menaungi

4. Profesi harus diambil sebagai pemenuhan panggilan hidup.

Jelas sekali bahwa yang namanya kode etik adalah suatu yang sangat urgent, di samping sebagai syarat guru bisa dikatakan sebagai profesi, kode etik juga yang akan 
menjadi salah satu panduan bagaimana tingkah laku pelaku profesi tersebut. Kode etik seorang guru yaitu:

1. Guru berbakti membimbing peserta didik untuk membentuk manusia Indonesia seutuhnya yang berjiwa Pancasila

2. Guru memiliki dan melaksanakan kejujuran professional

3. Guru berusaha memperoleh informasi tentang peserta didik sebagai bahan melakukan bimbingan dan pembinaan

4. Guru menciptakan suasana sekolah sebaik-baiknya yang menunjang berhasilnya proses belajar mengajar

5. Guru memelihara hubungan baik dengan orang tua murid dan masyarakat sekitarnya untuk membina peran serta dan bertanggung jawab bersama terhadap pendidikan

6. Guru secara pribadi dan bersama-sama mengembangkan dan meningkatkan mutu dam martabat profesinya

7. Guru memelihara hubungan seprofesi, semangat kekeluargaan, dan kesetiakawanan sosial

8. Guru secara bersama-sama memelihara dan meningkatkan mutu PGRI sebagai sarana perjuangan dan pengabdian

9. Guru melaksanakan segala kebijaksanaan pemerintah dalam bidang pendidikan.

Demikian juga bahwa guru bisa dikatakan sebagai guru profesional ketika ia memiliki kompetensi dasar sebagai guru. Kompetensi guru menjadi suatu hal yang sangat penting dalam mengelola pengajaran kepada peserta didik. Adapun kompetensi yang harus dimiliki yaitu:

1. Kompetensi Pedagogik

Kompetensi pedagogik adalah kemampuan guru dalam pengelolaan pembelajaran peserta didik yang sekurang-kurangnya meliputi:

1) Pemahaman wawasan atau landasan kependidikan.

2) Pemahaman terhadap peserta didik.

3) Pengembangan kurikulum atau silabus.

4) Perencanaan pembelajaran.

5) Pelaksanaan pembelajaran yang mendidik dan dialogis.

6) Pemanfaatan teknologi pembelajaran.

7) Evaluasi hasil balajar. 
8) Pengembangan peserta didik untuk mengaktualisasikan berbagai potensi yang dimilikinya (Undang-undang Republik Indonesia, 2012, p.229).

2. Kompetensi Kepribadian

Kompetensi kepribadian adalah kemampuan kepribadian yang sekurang-kurangnya mencakup kepribadian yang:

1) Beriman dan bertakwa.

2) Berakhlak mulia.

3) Arif dan bijaksana.

4) Demokratis.

5) Mantap.

6) Berwibawa.

7) Stabil.

8) Dewasa.

9) Jujur.

10) Sportif.

11) Menjadi teladan bagi peserta didik dan masyarakat.

12) Secara obyektif mengevaluasi kinerja sendiri.

13) Mengembangkan diri secara mandiri dan berkelanjutan (Undang-undang Republik Indonesia, 2012, p.229).

3. Kompetensi Profesional

Kompetensi profesional adalah kemampuan guru dalam menguasai pengetahuan bidang ilmu pengetahuan, teknologi, dan/atau seni dan budaya yang diampunya yang sekurang-kurangnya meliputi penguasaan:

1) Materi pembelajaran secara luas dan mendalam sesuai dengan standar isi program satuan pendidikan, mata pelajaran, dan/atau kelompok mata pelajaran yang akan diampu.

2) Konsep dan metode disiplin keilmuan, teknologi atau seni yang relevan, yang secara konseptual menaungi atau koheren dengan program satuan pendidikan, mata pelajaran, dan/atau kelompok mata pelajaran yang akan diampu (Undangundang Republik Indonesia, 2012, p.230).

\section{Kompetensi Sosial}

Kompetensi sosial adalah kemampuan guru sebagai bagian dari masyarakat yang sekurang-kurangnya meliputi kompetensi untuk: 
1) Berkomunikasi lisan, tulis, dan/atau isyarat secara santun.

2) Menggunakan teknologi komunikasi dan informasi secara fungsional.

3) Bergaul secara efektif dengan peserta didik, sesama pendidik, tenaga kependidikan, pimpinan satuan pendidikan, orang tua/wali peserta didik.

4) Bergaul secara efektif dengan masyarakat sekitar dengan mengindahkan norma serta sistem nilai yang berlaku.

5) Menerapkan prinsip persaudaraan sejati dan semangat kebersamaan (Undangundang Republik Indonesia, 2012, p.230).

Melihat tugas dan peran guru yang begitu kompleks dengan tugas yang sangat berat yaitu untuk menjadikan anak-anak bangsa menjadi seorang yang memiliki kecerdasan IQ, EQ, dan SQ sehingga bisa menjadi manusia seutuhnya. Dengan begitu maka Implikasinya adalah kemajuan bangsa. Sebuah proses panjang yang tidak bisa langsung dinikmati dengan sekejap mata. Untuk menunjang keberhasilan pencapaian tugas yang berat ini maka perlu bagi semua pihak agar mau berbenah serta mendukung. Tak hanya dari segi guru tetapi semua pihak juga harus ikut berbenah agar dapat menunjang keberhasilan pendidikan Indonesia.

\section{Tugas dan Peran Guru Menurut Perspektif Pendidikan Islam}

Menurut perspektif pendidikan Islam, guru di samping bertugas sebagai pembina dan pengajar anak didik, guru juga bertugas dan berperan sebagai berikut:

\section{Korektor}

Sebagai korektor, guru harus bisa membedakan mana nilai yang baik dan mana nilai yang buruk. Kedua nilai yang berbeda ini harus betul-betul dipahami dalam kehidupan di masyarakat. Kedua nilai ini mungkin telah anak didik miliki dan mungkin pula telah mempengaruhi sebelum anak didik masuk sekolah. Latar belakang kehidupan anak didik yang berbeda-beda sesuai dengan sosio-kultural masyarakat tempat anak didik tinggal akan mewarnai kehidupannya (Hasan Basri, 2014, p.84).

2. Inspirator

Sebagai inspirator, guru harus dapat memberikan ilham yang baik bagi kemajuan belajar anak didik. Persoalan belajar adalah masalah utama anak didik. Guru harus dapat memberikan petunjuk bagaimana cara belajar yang baik. Petunjuk itu tidak harus bertolak dari sejumlah teori belajar, dari pengalaman pun bisa dijadikan petunjuk bagaimana cara belajar yang baik. Yang penting bukan teorinya, tetapi 
bagaimana melepaskan masalah yang dihadapi oleh anak didik (Hasan Basri, 2014, p.84).

3. Informator

Sebagai informator, guru harus dapat memberikam informasi perkembangan dan pengetahuan teknologi, selain sejumlah bahan pelajaran untuk setiap mata pelajaran yang telah diprogramkan dalam kurikulum. Informasi yang baik dan efektif diperlukan dari guru. Kesalahan informasi adalah racun bagi anak didik. Untuk menjadi informator yang baik dan efektif, penguasaan bahasa sebagai kuncinya, ditopang dengan penguasaan bahan yang akan diberikan kepada anak didik. Informator yang baik adalah guru yang mengerti apa kebutuhan anak didik. Informator yang baik adalah guru yang mengerti apa kebutuhan anak didik dan mengabdi untuk anak didik (Hasan Basri, 2014, p.84).

4. Organisator

Organisator adalah sisi lain dari peranan yang diperlukan dari guru. Dalam bidang ini, guru memiliki kegiatan pengelolaan kegiatan akademik, menyusun tata tertib sekolah, menyusun kalender akademik, dan sebagainya. Semuanya diorganisasikan sehingga dapat mencapai efektifitas dan efisiensi dalam belajar pada diri anak didik (Hasan Basri, 2014, p.84).

5. Motivator

Sebagai motivator, guru hendaknya dapat mendorong anak didik agar bergairah dan aktif belajar. Dalam upaya memberikan motivasi, guru dapat menganalisis motifmotif yang melatarbelakangi anak didik malas belajar dan menurun prestasinya di sekolah. Setiap saat, guru harus bertindak sebagai motivator, karena dalam interaksi edukatif tidak mustahil ada di antara anak didik yang malas belajar dan sebagainya (Hasan Basri, 2014, p.85).

6. Inisiator

Dalam peranannya sebagai inisiator, guru arus dapat menjadi pencetus ide-ide kemajuan dalam pendidikan dan pengajaran. Proses interaksi edukatif yang ada sekarang harus diperbaiki sesuai perkembangan ilmu pengetahuan dan teknologi di bidang pendidikan. Kompetensi guru harus diperbaiki, keterampilan penggunaan media pendidikan dan pengajaran harus diperbarui sesuai kemajuan media komunikasi dan informasi abad ini (Hasan Basri, 2014, p.85).

7. Fasilitator 
Sebagai fasilitator, guru hendaknya dapat menyediakan fasilitas yang memungkinkan kemudahan dalam kegiatan belajar anak didik. Lingkungan belajar yang tidak menyenangkan, suasana ruang kelas yang pengap, meja dan kursi yang berantakan, fasilitas belajar yang kurang tersedia, menyebabkan anak didik malas belajar. Oleh karena itu, menjadi tugas guru bagaimana menyediakan fasilitas, sehingga akan tercipta lingkungan belajar yang menyenangkan anak didik (Hasan Basri, 2014, p.85).

8. Pembimbing

Peranan guru yang tidak kalah pentingnya dari semua peran yang disebutkan di atas, adalah sebagai pembimbing. Peranan ini harus lebih dipentingkan karena kehadiran guru di sekolah adalah untuk membimbing anak didik menjadi manusia dewasa susila yang cakap. Tanpa bimbingan, anak didik akan mengalami kesulitan dalam menghadapi perkembangan dirinya. Kekurangmampuan anak didik menyebabkan lebih banyak tergantung pada bantuan guru. Tetapi semakin dewasa, ketergantungan anak didik semakin berkurang. Jadi, bagaimanapun bimbingan dari guru sangat diperlukan pada saat anak didik belum mampu berdiri sendiri (mandiri) (Hasan Basri, 2014, p.86).

\section{Demonstrator}

Dalam interaksi edukatif, tidak semua bahan pelajaran dapat anak didik pahami. Apalagi anak didik yang memiliki inteligensi yang sedang. Untuk bahan pelajaran yang sukar dipahami anak didik, guru harus berusaha dengan membantunya, dengan cara memperagakan apa yang diajarkan secara didaktis, sehingga apa yang guru inginkan sejalan dengan pemahaman anak didik, tidak terjadi kesalahan pengertian antara guru dan anak didik. Tujuan pengajaran pun dapat tercapai dengan efektif dan efisien (Hasan Basri, 2014, p.86).

10. Pengelola Kelas

Sebagai pengelola kelas, guru hendaknya dapat mengelola kelas dengan baik karena kelas adalah tempat terimpun semua anak didik dan guru dalam rangka menerima bahan pelajaran dari guru. Kelas yang dikelola dengan baik akan menunjang jalannya interaksi edukatif. Sebaiknya, kelas yang tidak dikelola dengan baik akan menghambat kegiatan pengajaran (Hasan Basri, 2014, p.86).

11. Mediator 
Sebagai mediator, guru hendaknya memiliki pengetahuan dan pemahaman yang cukup tentang media pendidikan dalam berbagai bentuk dan jenisnya, baik media nonmateriil maupun materiil. Media berfungsi sebagai alat komunikasi guna mengefektifkan proses intraksi edukatif. Keterampilan menggunakan semua media itu harus sesuai dengan pencapaian tujuan pengajaran. Sebagai mediator, guru dapat diartikan sebagai penengah dalam proses belajar anak didik. Dalam diskusi, guru berperan sebagai penengah, sebagai pengatur lalu lintas jalannya diskusi (Hasan Basri, 2014, p.87).

\section{Supervisor}

Sebagai supervisor, guru hendaknya dapat membantu, memperbaiki, dan menilai secara kritis proses pengajaran. Teknik-teknik supervisi harus dikuasai dengan baik agar dapat melakukan perbaikan dalam belajar mengajar. Untuk itu, kelebihan yang dimiliki supervisor bukan hanya karena posisi atau kedudukan yang ditempatinya, tetapi juga karena pengalaman, pendidikan, kecakapan, atau keterampilanketerampilan yang dimilikinya, atau karena memiliki sifat-sifat kepribadian yang menonjol dari pada orang-orang yang ada di bawah pengawasannya (Hasan Basri, 2014, p.87).

\section{Evaluator}

Sebagai evaluator, guru dituntut untuk menjadi seorang evaluator yang baik dan jujur, dengan memberikan penilaian yang menyentuh aspek ekstrinsik dan intrinsik. Penilaian terhadap aspek kepribadian anak didik, yakni aspek nilai. Berdasarkan hal ini, guru harus bisa memberikan penilaian dalam dimensi yang luas. Penilaian terhadap kepribadian anak didik tentu lebih diutamakan dari pada penilaian terhadap jawaban anak didik ketika diberikan tes. Anak didik yang berprestasi baik, belum tentu memiliki kepribadian yang baik. Jadi, penilaian itu pada hakikatnya diarahkan pada berubahan kepribadin anak didik agar menjadi manusia susila yang cakap (Hasan Basri, 2014, p.87).

\section{Kesimpulan}

Menjadi guru adalah pekerjaan yang sungguh mulia. Ia bertanggung jawab tidak hanya menjadikan para anak manusia pandai di bidang ilmu pengetahuan, tetapi juga bermoral baik dalam kehidupan ini. Seorang anak manusia yang pada mulanya tidak mengerti apa-apa, di hadapan seorang guru dididik untuk memahami kehidupan secara 
lebih baik dan mengenal dunia. Di pundaknyalah ada tugas dan tanggung jawab keberlangsungan masa depan generasi yang lebih cerdas dan berperadapan.

Begitu mulia pekerjaan seorang guru sekaligus betapa berat tugas dan tanggung jawab menjadi seorang guru. Inilah mengapa tidak semua orang bisa menjadi seorang guru yang berhasil. Hanya orang-orang tertentu yang mempunyai rasa cinta terhadap anak-anak atau peserta didik dan berdedikasi tinggi terhadap dunia pendidikan saja yang mampu menjadi seorang guru. Inilah pribadi seorang guru yang berhasil mengajar sekaligus mendidik di hadapan murid-muridnya, sosok seorang guru favorit yang dicintai oleh anak didiknya.

Menurut perspektif pendidikan Islam, guru di samping bertugas sebagai pembina dan pengajar anak didik, guru juga bertugas dan berperan sebagai berikut: 1. Korektor, 2. Inspirator, 3. Informator, 4. Organisator, 5. Motivator, 6. Inisiator, 7. Fasilitator, 8. Pembimbing, 9. Demonstrator, 10. Pengelola Kelas, 11. Mediator, 12. Supervisor, 13. Evalator.

\section{Daftar Rujukan}

Azzet, Akhmad Muhaimin (2011). Menjadi Guru Favorit. Cetakan I. Jogjakarta: Ar-Ruzz Media.

Basri, Hasan (2014). Filsafat Pendidikan Islam. Bandung: CV Pustaka Setia.

Busthomi, Yazidul (2018). Modal Utama agar Menjadi Guru Favorit bagi Peserta Didiknya. Paciran Lamongan: STIT Muhammadiyah.

Busthomi, Yazidul (2021). Etika Guru Menurut Perspektif Pendidikan Agama Islam. Paciran Lamongan: STIT Muhammadiyah.

Enco Mulyasa (2011). Menjadi Kepala Sekolah Profesional. Bandung : Remaja Rosdakarya.

Fatih syuhud (2008). Santri Pesantren dan Tantangan Pendidikan Islam, cetakan II. Pagelaran: Pustaka Alkhoirot.

Subhan Adi Santoso, Ali Mustofa, 2019. Ilmu Pendidikan Islam Era Industri 4.0. Malang: Media Sutra Tiga

Subhan Adi Santoso, 2017. Pengaruh Kompetensi Pedagogik Guru Terhadap Prestasi Belajar Siswa Kelas XI Mata Pelajaran PAI Di SMKN 13 Malang. Jurnal Tamaddun: Vol. 18 No. 2

Subhan Adi Santoso, 2020. Media Pembelajaran Pendidikan Agama Islam Era Industri 4.0. Yogyakarta: Deepublish 
Subhan Adi Santoso, M. Chotibuddin, 2020. Pembelajaran Blended Learning Masa Pandemi. Pasuruan: Qiara Media

Subhan Adi Santoso, Himmatul Husniyah, 2021. Pendidikan Agama Islam Berbasis IT. Yogyakarta: Zahir Publishing

Syah, Muhibbin (2008). Psikologi Pendidikan dengan Pendekatan Baru. Cetakan XIIII. Bandung: PT Remaja Rosdakarya.

Tafsir, Ahmad (2014). Ilmu Pendidikan dalam Perspektif Islam. Cetakan XI. Bandung: PT Remaja Rosdakarya.

Undang-undang Republik Indonesia No.14 tahun 2005 tentang guru dan dosen (2012) Undang-Undang Tentang Guru dan Dosen. Bandung: Citra Umbara.

Zuhairini (2015). Filsafat Pendidikan Islam. Cetakan II. Jakarta: Bumi Aksara. 
Yazidul Busthomi

168 Volume 8 No. 1, 1 Maret 2022 